\title{
Reconsidering mediatization of religion: Islamic televangelism in India
}

Media, Culture \& Society

(C) The Author(s) 2016

Reprints and permissions:

sagepub.co.uk/journalsPermissions.nav DOI: $10.1177 / 01634437 \mid 6679032$

mcs.sagepub.com

@SAGE

\section{Patrick Eisenlohr}

Georg-August-Universität Göttingen, Germany

\begin{abstract}
This article proposes a rethinking of religion and mediatization by differentiating between two intersections of religion and media, public religion and religious mediation. I argue that whenever religious change that can be usefully described as mediatization occurs it can best be captured as an effect resulting from the interaction of these two dimensions. Extending the debate on religion and mediatization beyond Christian North Atlantic contexts, I compare two instances of Islamic televangelism in India in order to illustrate the diversity of configurations of public religion and religious mediation even within the same regional setting and religious tradition. My analysis greatly complicates an assessment of mediatization as the subsumption of religion under an extraneous media apparatus, pointing at the highly uneven nature of media-related religious transformation and the ongoing domestication of contemporary media practices into established religious paradigms.
\end{abstract}

\section{Keywords}

India, Islam, mediatization, public sphere, religion, televangelism

In recent years, there has been a surge of interest in the transformation of religion against the background of new media practices. In an effort to analytically capture these transformations, a number of scholars have proposed that we are currently witnessing a mediatization of religion that is reshaping religious practices, institutions, and traditions. Mediatization as a process of social and cultural change has been conceived in varying ways. According to some scholars, mediatization means that the formats and institutions of contemporary media increasingly shape other aspects of social and cultural life

\section{Corresponding author:}

Patrick Eisenlohr, Georg-August-Universität Göttingen, Waldweg 26, Göttingen 37073, Germany.

Email: peisen|@uni-goettingen.de 
(Lundby, 2009; Schulz, 2004). In this understanding of mediatization, politics and society are being reconfigured according to the structural and institutional logics of media. The main proponent of the thesis of a mediatization of religion, Stig Hjarvard, regards it as the subsumption of religious practices and institutions under the institutional 'medialogics' of newer forms of media (Hjarvard, 2008: 11, 2016: 9). Alternatively, other scholars have argued that such mediatization is a meta-process that influences religion, among other domains, by introducing changes in the structures of communication more generally (Krotz, 2009), while others have portrayed mediatization of religion as the outcome of a two-way interaction between the fields of media and religion (Hepp, 2009).

In this article, I seek to reconsider mediatization of religion. I do so by differentiating between two dimensions of the intersection of media and religion. These are religion in the public sphere and religious mediation, by which I understand processes of interaction between human actors and the divine along with the institutions and authorities that sustain them (Eisenlohr, 2012: 38). Especially the latter dimension draws attention to a fundamental inseparability of religion and media, a point that needs to be kept in mind for a discussion of present-day mediatization of religion. In order to illustrate my argument, I draw on a comparison between two instances of Islamic televangelism in India. Although my examples both concern Islam in the same regional context, they display different interrelationships between these two fundamental aspects of the nexus of media and religion, resulting in different degrees and directions of religious transformation. Instead of arguing for an overall transformation of religion through the latter's mediatization, I suggest that mediatization plays itself out in rather divergent ways across religious contexts. Whether it is useful to speak of mediatization of religion depends on the interactions between public religion and religious mediation in particular settings. The growing significance of contemporary media in religious contexts is associated with varying degrees of religious change. It involves significant religious transformations in some religious settings, while leading to the domestication of new media practices into religious contexts with minimal religious change in others. My focus on Islam in contemporary India also contributes to broadening the debate on the mediatization of religion beyond Christian and North Atlantic contexts, which so far have overwhelmingly featured in this debate. It thus helps to clarify whether mediatization of religion is just a phenomenon of post-Christian societies, especially in Northern Europe, or a process of broader global concern.

\section{Mediatization versus mediation}

An important difference between different conceptions of mediatization lies in the question whether the social and cultural changes that mediatization brings about can only be found in late modernity or whether they have also occurred at other times. While some authors such as Krotz (2009) hold that mediatization, including mediatization of religion, has occurred throughout history, Lundby (2009) maintains that mediatization 'points to societal changes in contemporary high modern societies and the role of the media and mediated communication in these transformations' (p. 1). The focus on the contemporary is also characteristic of Hjarvard's understanding of mediatization of religion as a decidedly late modern phenomenon prevalent in post-Protestant societies of northern Europe. In his view, the increasing dependence of religion on media has led to profound 
transformations of religious authority away from central religious institutions towards greater individualization of religious experiences and inclinations along with a weakening of institutionalized forms of religion (Hjarvard, 2016). This is coupled with a rise of what Hjarvard (2008) calls 'banal religion' (p. 14) as religious symbols and themes increasingly blend with popular culture in the media, who replace religious institutions as the principal source of information about religion.

Arguing against the idea that 'religion is increasingly subsumed under the logic of media' (Hjarvard, 2008: 11), other scholars in the fields of religious studies, anthropology, and philosophy have pointed to intrinsic links between religion and media that have always been at the base of religious practices and institutions (Meyer, 2013; Morgan, 2011; Stolow, 2005). These links are especially evident in interactions between humans and religious otherworlds which necessarily involve the use of media such as images, including reproduced images, spoken and printed language, sacred objects, sound reproduction, and in the contemporary world the entire range of digital audiovisual media supported by the Internet. As David Morgan (2011) has put it, 'if mediatization is a media makeover of religion, must we not concede it has happened many times before?' (pp. 140-141). At any rate, this line of research suggests that the intertwining of religion and media is not necessarily a sign of the former's weakening or banalization. Furthermore, unlike Hjarvard's notion of a one-sided subsumption of religion under a media logic, proponents of such a 'mediation-approach' note that the inherent links between religion and media can also function as the base for mutual influences between religion and media. Also, in contrast to theorists of 'media logic' mediatization, they have stressed how religious traditions and theologies have shaped media users' ideas of what media are and what they accomplish. This approach not only shares many similarities with the paradigm of 'mediation' as understood by Couldry (2008), postulating a dialectic relationship between institutionalized media and other spheres of social life, but even evokes the notion of 'domestication' of media into preexisting social and cultural settings (Silverstone and Hirsch, 1992). If for scholars of religion, the inseparability of religion and media has recently emerged as a key theme, stressing how from a phenomenological perspective, media enable religious experiences and sensations to begin with, this has also resulted in greater attention to how changes in the materiality of such media also imply religious transformations (Meyer, 2013).

\section{Religion in the public sphere and religious mediation}

Religion is an integral part of contemporary public spheres, and contemporary religious experiences and practices are deeply shaped by the mediated circulation of religious discourse and images. The observation that contemporary religious movements make use of modes of mobilization and interaction that are characteristic of modern public spheres has led to valuable insights into present-day religious dynamics (Larkin, 2008; Meyer and Moors, 2006). Key characteristics of public spheres, such as stranger sociability through the routine circulation of discourse and images far beyond face-to face radius and the simultaneity of both personal and impersonal address in public discourse (Warner, 2002) are of prime importance for understanding religion today. Research on religion in the public sphere has also led to a critique of purified notions religion by 
demonstrating how religion blends with advertisement and entertainment, underlining the importance of visceral attachments and sensations for religious practices and identities. Research on religious markets (Clark, 2007) has also shown how the public circulation of religious discourse and images unfolds in contexts of often intense competition that are continuous with the functioning of capitalist markets, while a related aspect of this intersection between capitalist market logics and contemporary religious activism are attempts at 'branding religion' (Hepp and Krönert, 2009).

Research on religion and the public sphere has thus highlighted the centrality of contemporary media practices for understanding religion in the contemporary world. At the same time, there has also been a steadily growing exploration of what some have called the intrinsic links between religion and media (De Vries, 2001). Scholars who are inspired by what some call a 'media turn' in the study of religion (Engelke, 2010) investigate religious mediation in a stricter sense, as a process of interaction between human actors and a religious otherworld, however conceived, that necessarily involves media with their material and technological aspects. Religion is here conceived as a performative process of communicative exchange relating people to spiritual or divine realms, a process that often involves broad ranges of the sensorium. 'Sensational forms' (Meyer, 2008) thus play a leading role in religion as a form of mediated interaction. One of the consequences has been a heightened awareness of the material dimensions of media enabling such exchange and interaction. An interesting question in this line of research is the articulation between the material and technological aspects of particular media and religious conceptualizations of the interactions between humans and the divine, possibly accounting for elective affinities between particular religious traditions and certain media practices.

While research on religion and the public sphere and religious mediation in the sense I have outlined above has expanded at a rapid pace, there remains much work to be done to account for the interrelations between both these dimensions, as most research to date has tended to address only one of these two key modes in which religion and media are intertwined in the contemporary world (Eisenlohr, 2012). While work on religion and the public sphere investigates the interactions between human actors through the circulation of religious discourse and images, analyses of religious mediation focus on the interactions between human and divine or spiritual actors mostly located in a non-perceptible realm. However, these two kinds of interaction are closely interrelated. In this article, I explore their interconnections, with the aim to arrive at a reconsideration of the mediatization of religion. Both of these dimensions are sensitive to the relation between media and other forms of social change, public religion in particular emphasizes the interactions of religion with other domains through the changing modalities of circulating discourse and images that constitute the public sphere.

Drawing on such approaches that stress the intertwining of media and religion, I seek to reconsider the mediatization of religion in the contemporary world. I propose that mediatization of religion can be best conceptualized as an effect resulting from the interaction between the public sphere dimensions of religion and processes of religious mediation. Tied to older, established religious paradigms of interaction with a spiritual otherworld, the sphere of religious mediation sometimes exhibits greater inertia and resistance to change in transformed media environments, and indeed often constitutes a 
force for the domestication of new media practices and technologies into the established paradigms of interaction between humans and the divine that dominate the religious tradition in question. The latter could be attested for many uses of sound reproduction technology in Islamic settings informed by the Qur'anic paradigm of 'logocentric recitationalism' (Messick, 1993: 21-25), according to which artful recitation summons the divine (Eisenlohr, 2009). The public sphere dimensions of religion, however, only emerged in early modernity with the rise of public spheres in Europe and North America and their subsequent spread around the world in the context of colonialism and imperialism. Public religion is often receptive to processes of social and cultural change that can be captured under the label mediatization. The public circulation of religious discourse and images interacts with other components of the public sphere such as advertising, entertainment, consumption, and political deliberation. Therefore, the public sphere is a likely direction from which new crossovers, genres, practices, and institutional forms in the field of media tend to enter religious uses of media, where they also may change patterns of religious mediation (Hirschkind, 2006; Meyer and Moors, 2006). Nevertheless, it is clear that powerful older paradigms of religious mediation, such as darshan, the intense visual interaction between devotees and deities in Hinduism that can also involve tactile sensations (Pinney, 2002) also exert influence on media in the wider public sphere, as is, for example, evident in darshan-esque visual techniques in Indian popular films and television sitcoms (Vasudevan, 2011). Another related example is the spread of a 'pentecostalite' visual style in the Ghanaian public sphere (Meyer, 2004). Whether such crossovers and influences lead to the sort of significant changes that can usefully be described as mediatization depends on the interaction between established forms of religious mediation and the public sphere dimensions of religion. Distinguishing these different intersections of media and religion allows one to empirically investigate the question of the mediatization of religion as the outcome of the interaction between public religion and religious mediation.

To this end, I compare two examples of Islamic televangelism in India, the programs of the Salafist preacher Zakir Naik of the Mumbai-based Islamic Research Foundation (http://www.irf.net) and its associated TV channel Peace TV (http://www.peacetv.tv) and the programming of the Mumbai-based Twelver Shi'ite World Islamic Network (http:// www.winislam.com) associated with Ayatollah Sistani in Najaf, Iraq. Both of these networks employ new and similar media genres, and draw on new media practices in their Islamic propagation. Their sectarian affiliations and their institutional settings and structures are, however, very different. In this article, I compare the intersection of public religion and religious mediation in these two related, but also contrasting scenarios in order to gain insights about processes of mediatization of Islam in its post-liberalization Indian context. Comparing the mediatization of religion in these rather divergent Indian settings will contribute to a better understanding of the process of social change associated with the introduction of new media practices in the field of religion.

\section{Contemporary media and Islam}

There is a growing literature analyzing transformations in the world of Islam in the context of new media practices (Eickelman and Anderson, 1999; Elsayed, 2016; Hirschkind, 
2006). Work on Islam and the public sphere has emphasized the role of so-called 'small media', (Sreberny-Muhammadi and Muhammadi, 1994) such as audio- and videocassettes as well as audio-and video CDs and the Internet in undercutting the dominance of established players such as state institutions seeking to regulate religion as well as the 'ulema (pl. of 'alim, Islamic legal scholar). According to some scholars, in contrast to traditional broadcast media whose operation requires a lot of funds and who can be more easily be controlled, newer media practices have led to a democratization of Islamic authority in many parts of the world, and have given dissenting views more opportunities to express themselves, aiding the emergence of an Islamic civil society (Eickelman, 2005). A dominant theme in these writings is the transformation of Islamic authority in the context of new media practices. At the same time, scholars have investigated the emergence of Islamic 'counterpublics' (Hirschkind, 2006; Sreberny-Muhammadi and Muhammadi, 1994) that stand in a relation of difference and opposition to national mainstream publics.

However, scholars have also been concerned with the integration of newer media technologies into established religious practices in the interaction between Muslims and the divine. Uses of sound reproduction technology have featured quite prominently in this literature, such as concerning the call to prayer, and in the circulation of discourse devotional practices in the veneration of the Prophet and of Sufi saints (Eisenlohr, 2009; Khan, 2011). The attention to voice and recitation built into the Qur'anic paradigm as the predominant site where God reveals himself has led to a predictable interest in uses of sound reproduction technologies as a means to enhance interaction with the divine. But the centrality of the reciting voice in Islamic traditions notwithstanding, there are also rich Islamic visual cultures which have become progressively integrated with the latest audiovisual media (Moll, 2010).

Combining the dimensions of voice and visual performance, televangelism (Bruce, 1990; Hoover, 1988) is a media genre that has been eagerly adopted in Islamic contexts (Moll, 2010). A pioneer in this regard was the Indian-born South African preacher Ahmad Deedat (1918-2005), whose videocassettes were widely circulated throughout Africa (Larkin, 2008; Westerlund, 2003). Espousing a variety of Saudi-inspired Salafist Islam, Deedat was also very conscious of the North American Protestant origins of the media genre, which he skillfully deployed to create situations of conflictual dialogue with Christianity. His eloquent command of English and his display of scriptural knowledge not only in Islamic traditions, but also from the Bible that he used to score points against Christianity resonated powerfully among his predominantly African audiences. Deedat thus created a new Islamic media format that combined the deliberative dimensions of scriptural knowledge and discussion, the visual performance of authority, as well as drawing on an originally 'Western' media genre that itself indicated values of modernity for many of its viewers. Another prominent feature of Deedat's media enterprise was his status as a self-taught and self-appointed 'new interpreter' of Islam, who did not undergo traditional training as an 'alim. With this, he set a trend followed by others such as the Qatar-based Egyptian televangelist Yusuf al-Qaradawi (who is in fact a traditionally trained scholar, see Gräf and Skovgaard-Petersen, 2009), Amr Khaled in Egypt (Rock, 2010), or more recently Aamir Liaquat in Pakistan, as well as Zakir Naik in India, whose programs are one of the examples I draw in this article, and who on the website of his 
television channel claims to have been described as 'Deedat plus' by Ahmad Deedat himself. Televangelism is not just a new technique of propagating Islam. It is also part of a broader trend in the Muslim world of creating forms of Islam that stress self-management, self-help, and individual responsibility, and are therefore highly business-friendly and often compatible with discourses and the disciplinary regimes of neoliberalism (Rudnyckyj, 2010).

\section{Islam in the Indian context}

In India, present-day Islam is largely the product of reformist movements that arose in 19th-century colonial India, primarily the schools of Bareilly, Deoband, and the Ahl-e Hadith. After the loss of traditional court patronage under British colonial rule and after the failed rebellion in 1857, the religious establishment successfully sought new spheres of activity and sustenance. They implemented new forms of religious education influenced by Western models of instruction (Metcalf, 1982), and gradually established themselves as leaders of a modern Muslim public making full use of the technologies, modes of circulation, travel, and debate that the rise of a modern public sphere had made available. At the same time, Islamic traditions also played a part in the twin processes of standardization and communalization of religion that played itself out in an expanding colonial public sphere (Freitag, 1989; Reetz, 2006). A new stress on individual moral responsibility accompanied these modern religious mobilizations that were part of a larger reconfiguration of religious identities also leading to the nationalization of religions under the impact of middle-class-based bourgeois social reform movements (Van Der Veer, 2001). Islamic reform movements' attempts to standardize and purify religious traditions at a time when religious organization, associational life and the structures of religious authority underwent great transformation also led to increased intra-Muslim sectarianism.

After partition and independence in 1947, the forces of religious communalism continued to have a severe impact on Muslims in postcolonial India who after the departure of much of their elite to Pakistan now found themselves in an increasingly impoverished and marginalized position. They have also been the victims of recurrent rounds of pogrom-like violence by Hindu nationalists. At the same time, the recent economic ascent of India and the corresponding rise of a new middle class (Brosius, 2010; Fernandes, 2006) have made Muslim marginalization and exclusion even more obvious in present-day India, as these developments have largely bypassed the Muslim minority. Religious communalism and sectarianism, the precariousness of their citizenship, and often severe socio-economic deprivation tend to be overall characteristics of Muslim life in contemporary India (Hansen, 2007). However, even though many of the opportunities of consumption and associated middle-class lifestyles are only available to a small minority among Muslims, their media worlds have also been reshaped by the overall drastic transformations of Indian mediascapes since 1991. That year marked the transition from a state monopoly of radio and television broadcasting in the service of nationbuilding and development to a liberalized media landscape marked by extreme proliferation of and competition between private sector media outlets, above all in Indian languages (Rajagopal, 2001; Rao, 2010). Far from completely displacing older Indian 
visual traditions, new forms of youth programming such as MTV integrated modes of media performance associated with the recent liberalization of the Indian economy with older styles emphasizing sentimentality, family, and friendship (Fernandes, 2006: 46; Juluri, 2003). At the same time, since the 1980s, new forms of media-based religious activism and programming have also emerged (Lutgendorf, 1995; Mankekar, 1999). One interesting feature has been the religious adoption of new middle-class-associated media genres for religious purposes, such as new talk and call-in shows. Here, I compare different varieties of one particular new media genre, Islamic televangelist programming among Muslims in India.

\section{Zakir Naik and Peace TV}

Mumbai-based Zakir Naik is currently the most popular Indian Islamic televangelist, and through his transnationally broadcasting TV channel also one of the best-known Islamic media personalities worldwide. His Islamic satellite television channel Peace TV was launched in October 2006 and broadcasts globally from Dubai. With programming in English and Hindi/Urdu, it addresses mainly a Salafi public - Sunni Muslims who claim to follow the ideas and practices of the pious ancestors (al-salaf al sālih) and advocates returning to the Quran and Sunnah by using ijtihād, independent reasoning. The audience of the channel are mainly from India, Pakistan and Bangladesh, and also from the Middle East, South Africa, and Great Britain. The Indian government banned the channel in 2012, but it continues to be available in several cities through semiformal cable TV operators and of course via the Internet, via its own website and youtube.com.

Expressing himself in English and flaunting his modern secular education as a medical doctor, Naik interprets religious texts and practices, and challenges globally circulating negative discourse on Islam as, for example, in the Peace TV programs Truth Exposed, Dare to Ask and Crossfire. A key characteristic of his style is his ambition to compare religions, in a manner reminiscent of Ahmad Deedat, including verbatim citing from scriptures and texts from Hinduism and Christianity, and his propensity for public debates with Christian and Hindu religious leaders. Another hallmark of his performances is his frequent references to modern science and its relevance in Islam. In his lectures and question-answer programs, Naik emphasizes theological similarities and underlying monotheism in Islam, Hinduism, and Christianity. He supports his arguments by giving references from the Bible, the Vedas and the Upanishads. Zakir Naik draws on a rhetoric of reason and logic to promote the universal character of Islam.

Naik's televangelist presence draws on established patterns on religious mediation in the narrow sense, by which I mean interactions between Muslims and the divine. These are foremost the frequent reference to scriptural sources, and the recitation of Quranic verses. Furthermore, Naik's televised presentation also involves discussion of hadith, the authoritative record of the words and deeds of the Prophet ideally traceable to his companions, or others who had directly witnessed the words and actions of the Prophet. Part of the process of religious mediation regarding hadith is the reckoning of their chains of transmission (isnad) stretching back to the surroundings of the Prophet, measured by the moral character, piety, and reliability of those having handed down the hadith. In other words, the reciting voice, and learned interpretation of scripture and hadith are central to 
the televisual performance as an act of religious mediation. One needs to add that Salafis such as Naik do not follow nor accept the authority of any of the four established legal schools of Sunni Islam, and that therefore legal exegesis in the framework of these traditions is not part of the process of religious mediation in his case. Even though the primacy of the reciting voice and textual interpretation is well established in Islamic traditions, there are also aspects of visual culture that constitute part of the process of religious mediation. These are foremost visual displays of piety, such as Zakir Naik's beard and his wearing of a white skullcap (taqiyah/topi), and an overall respectful, measured and authoritative bodily comportment and demeanor.

At the same time, the success and popularity of Naik's performance is due to its proximity to themes and forms of expression characteristic of broader public spheres, transcending the realm of established forms of religious mediation. First, he has adopted the question-answer show format for most of his televised performances to the purposes of Islamic propagation, and holds his meetings and televangelist performances at big concert or convention halls that are not normally religious spaces and are mostly used for a great variety of spectacles, lectures, and stage performances. In his lectures and programs, Naik makes frequent references to wider popular culture, world political events and conflicts, as well as broader social themes and issues that permeate public discussion and visual culture. The close dialogue with concerns of wider public importance across religious and ethnic lines is also palpable in the aesthetics of his comportment and dress. In addition to the skullcap and beard that one might expect from a pious Indian Islamic preacher, Zakir Naik also always wears a suit and tie, and invariably lets himself be addressed as Dr. Zakir Naik to stress the authority of his secular education and to underline a broader public respectability in line with corporate and bourgeois norms. The skillful fusion of Islamic authority, public respectability, and media stardom was underlined in 2013 when he was presented with the 'Islamic personality of the year award' by the ruler of Dubai and Prime Minister of the United Arab Emirates, in addition to the King Faisal International Prize he received from the Saudi government in 2015. Very importantly, Naik does not have the credentials of a traditional Islamic scholar; he is a selftaught expert in Islam with a secular academic education, and speaking and performing skills reminiscent of an entertainer or political leader in the public sphere. Naik is hence a prime example of a new self-appointed religious leader who competes with established religious authorities based on his successful use of modern media.

To sum up, the integration of the televangelist format into Salafist Islam in India has left core aspects of religious mediation such as the recitation of scripture and the exegesis of hadith unaltered. Nevertheless, the adoption of televangelism from its North American Protestant origins has led to marked changes in Indian Salafism as public religion. Among them is the introduction of the question-and-answer television show genre into religious propagation and the latter's migration away from established religious contexts into nontraditional settings associated with entertainment and business. The most significant change, however, concerns the structures of religious authority. It has enabled the rise of new actors in this field who on the basis of their speaking and performance skills as well as their secular education now inhabit the position of Islamic authorities, without the credentials of traditional religious training. The rise of new religious authorities such as Zakir Naik has been made possible by the relatively loose institutional structures of 
Salafism and, more broadly, Sunni Islam in India. The transformations of Naik's Salafist televangelism as public religion have even led to changes in the structures of religious mediation. Among these are the 'comparative' recourse to non-Islamic scriptural sources in order to enhance the interaction with the divine, as well as the frequent references to modern science in order to prove the superiority of Islam as a way of governing the relationships between God and human beings.

\section{Televangelism among Shi'ite Muslims in Mumbai: world Islamic network}

Twelver Shi'ite institutions in Mumbai are part of larger transnational networks of religious authority in the Shi'ite world that center on affiliations, financial and institutional ties, and relationships of accreditation with senior scholars recognized to be marja' $-e$ taqlid (sources of emulation) and the foundations directed by them. In Mumbai, as in India as a whole, Ayatollah Sistani in Najaf is by far the most influential marja', however the Supreme Leader of the Islamic Republic of Iran, Ayatollah Khamenei, is also vying for followers and influence among Twelver Shi'ites in Mumbai, through religious foundations and organizations tied to the leadership of the Islamic Republic of Iran.

In Mumbai, the importance of contemporary media practices for religious mobilizations in an urban environment is highly visible. There is above all the multitude of 'small media' (Sreberny-Muhammadi and Muhammadi, 1994) such as formerly cassettes, and now audio- and video CDs and DVDs through which also Muslims in the city circulate religious performances, speeches, and other content. Among Twelver Shi' ites in Mumbai, these are recordings of the devotional poetic mourning genres of marsiya and nauha, which commemorate the tragic events of the battle of Karbala in emotionally charged ways and express deep sorrow for the death of Hussain, the grandson of the Prophet, and other members of his family who perished in this battle in 680 AD. Audio or audiovisual recordings of the sermons and speeches of well-known Shi'ite 'alim are also popular. Many Shi'ites in Mumbai, for example, listen to digitized recordings of these poetic genres performed at devotional gatherings known as majlis (plural majalis) on CDs or view and listen to parts of such performances on local Shi'ite cable-television networks, on video CDs, or for some also through downloading such recordings from the Internet.

But contemporary Shi'ite media practices also comprise the watching of television programs that provide direct guidance in practical self-fashioning. In the predominantly Shi'ite south-central neighborhood of Dongri World Islamic Network (WIN), a Shi'ite media center established in 1991 that began with the distribution of Islamic books and brochures as well as free evening tuition classes for high school students. It gradually expanded its Islamic propagation into electronic media and produces not only 'small' devotional media such as video and audio-CDs, largely recordings of majalis and lectures, but alongside a website also runs a cable-television channel with its own production facilities, and has even recently begun satellite broadcasting. Especially younger people are very interested in question-answer style programs with Shi'ite 'ulema, and other programs that approach social issues and practical life problems from an Islamic perspective. In terms of aesthetics and forms of participation, these programs are very different from recordings of devotional events centering on lamenting the events at Karbala, which also 
feature extensively in WIN's programming. The latter are highly emotional occasions that are geared to provoke powerful emotions of grief and attachment in those witnessing them, a hallmark of Shi 'ite piety. In contrast, the more 'rational' programs, as some Shi'ite interlocutors referred to them are much more sober and professional in their appearance and mainly feature deliberative engagement and are more popular among younger viewers. As one of the producers at WIN put it, 'the youth want logic, and less emotion. They want rational debates, they want to know why are you saying this, what is your reference'. In some sense, such programs are a continuation of the center's longstanding ambitions to promote modern education among Mumbai Shi'ites. One of these programs is the WINproduced Hadees-e zindagi featuring a young woman in hijab interviewing a younger 'alim in a sleek-looking modern studio setting, asking questions that viewers had sent in per email, or were posing via the telephone live on air. Questions were all about practical life problems, requesting advice how to tackle them in an Islamically appropriate way. An additional program following a new format is Haqeeqat Today, a WIN-produced news program focused on issues of current public interest. In my research, I found that these programs are more popular among the younger generation, as they are responding to higher educational ambitions. Here, Shi'ite traditions become integrated with urban- and middle-class aspirations such as educational advancement that bring migrants to the megacity. This recasting of Shi 'ism evident in such programs is an example of a more activist tendency in the Shi'ite world since the Iranian revolution, in which Shi'ite tradition is reinterpreted as a new sense of agency and ambition to change social and political conditions, and therefore to actively strive to change one's fate in line with modernist narratives of hope, development and progress. Hadees-e zindagi and similar programs frame aspirations for better education, a greater sense of control over one's life and 'rational' selfimprovement in terms of religious tradition.

In sharp contrast to Zakir Naik's televangelism, the programming of WIN always features traditionally trained Shi'ite Islamic scholars. The media network is under the direct supervision of a scholar who is also the Mumbai vakil (representative) of Ayatollah Sistani in Najaf. There are no self-taught and self-appointed experts of Islam with a secular education in the world of Shi'ite Islam resembling Zakir Naik. In great contrast to the rather amorphous landscape of Sunni Islam, Twelver Shi'ism is characterized by a much more hierarchical and tightly structured religious establishment (marja iyya) ultimately centered on a very small number of clerics such as Sistani who have attained the highest possible rank of learning and scholarship. This key element of religious mediation characteristic of Shi'ite Islam appears not to have been changed in the context of new media practices.

Consequently, the visual cues of traditional religious authority feature prominently in WIN programming. Experts are all clerics with a traditional Islamic education, wearing the full garb characteristic of a Shi'ite 'alim. They are more likely to be viewed against backgrounds signaling their Islamic scholarship, such as filled bookcases. Also, the new WIN news and question-answer programs centered on themes of wider social and public interest are in close interaction with older established forms of performances and the related programs produced by WIN, such as sessions of collective mourning (azadari) for the members of the family of the Prophet murdered at Karbala, especially the socially mobilizing pain and outrage over their killing. Much of WIN's television programming is a clear extension of traditional forms of azadari, and in this case, newer forms of 
media clearly seem to have been domesticated into established religious practices without fundamentally changing them. Other key established elements of religious mediation are also in evidence in the new question-answer and news programs produced by WIN. As in Zakir Naik's televised performances, these are the recitation of Qur'anic verse, the discussion and exegesis of hadith while applying them to an issue in the present-day world. The reckoning of their chain of transmission (isnad) also characterizes WIN programming, here making particular reference to the established Twelver Shi'ite (Jafari) school of law.

Nevertheless, the new style programs heavily draw on themes and forms of expression characteristic of the wider public spheres. Among them are issues of youth culture and consumption. The aesthetics of Haqeeqat Today are reminiscent of the presentation style of national and international 24-hour news channels, with one difference being that many of the interviews and coverage of live events feature senior Shi'ite scholars expressing themselves on matters of broader social and world political interest. The program also features regular segments on 'career guidance' and 'innovative minds'. Frequently, modern studio environments are showcased as visual backdrop in programming, and in stark contrast to established formats of Shi' ite religious debate, young educated women wearing hijab sometimes play the roles of presenters. The issue of terrorism is one particular theme in current public debate that features very prominently in WIN programming. WIN programs denounce the association of terrorism and Islam, while accusing their Salafi or Wahhabi opponents to engage in or to promote terrorist attacks, including the frequent killing of Shi'ites by Sunni extremists in neighboring Pakistan.

Also in WIN's activism, there is a close interplay between elements of religious mediation in the narrow sense and the public sphere dimensions of religion. However, in contrast to Zakir Naik's Salafist televangelism, established components of religious mediation in the work of WIN seem to exhibit a greater resistance to the adoption of new globally circulating televangelist formats (Thomas and Lee, 2012), while on the other hand changes in the performance of religious authority and its associated styles of communication with a Shi'ite public are also evident. Clearly, core aspects of religious mediation, such as the recitation of scripture, exegesis of hadith, and the performance of azadari have been left largely unchanged by the introduction of WIN programming; indeed, it appears that television as a new medium has become domesticated into the practice of azadari that is so central to Twelver Shi'ism. Nevertheless, the repertoire of Twelver Shi'ite Islam as a public religion has also been markedly altered by the introduction of new televised genres, such as the question-and-answer show, and the news program with an Islamic slant. The studio settings of especially the latter genre indicate a significant departure from the aesthetics of established religious contexts, and the appearance of female presenters in these shows is also a break with the previously allmale-dominated traditional settings of Indian Shi'ism. But in contrast to Naik's Salafist televangelism such changes have not touched the structures of religious authority. WIN's programs remain under the supervision of the Shi'ite religious establishment which clearly uses them to extend their authority into parts of the public sphere where its authority was not present until recently. Traditionally trained male clerics with the sartorial insignia of their standing feature on these programs as the spokesmen of ultimate religious authority. Televangelist programming has therefore not led to the rise of new 
interpreters of Islam from outside the established religious hierarchies, and the robust institutional structures of transnational Shi'ism have succeeded in co-opting a changing mediascape for their own goals instead of being subverted by it. In the case of WIN, religious mediation has exerted influence on public Islam by extending established forms of religious mediation and its associated structures of authority into the public sphere. Media-induced changes in Twelver Shi' ism as a public religion have, however, not led to significant changes in the patterns of religious mediation and the forms of authority that come along with them.

\section{Conclusion}

Although both situated in Islamic contexts in India, the two examples I have discussed display marked differences in the social and religious changes that can be attributed to the introduction of new media practices. In both cases, core aspects of religious mediation have remained intact. Salafist televangelism clearly shows greater media-driven religious changes as far as its public sphere dimensions are concerned. Some of these changes have even filtered into the structures of religious mediation, especially its modes of authority. The Twelver Shi'ite programming of WIN, however, provides evidence for an opposite dynamic - there the structures of established religious mediation have been extended into the public sphere, while conversely media-induced changes to the Shi' ism propagated by WIN as a public religion have failed to bring about significant change in the sphere of religious mediation. In neither case can we speak of a 'subsumption' of religion under a 'media logic' conceived in institutional terms along the lines of Stig Hjarvard's thesis of the mediatization of religion. This is obvious in the case of WIN, but it also does not apply to Zakir Naik's Salafist televangelism. On the contrary, his televangelist channel is a media enterprise serving a religious movement rather than a manifestation of a nonreligious media institution impacting religion from the outside, submitting it to its own imperatives. But there are important influences that trends in the wider Indian public sphere exert on both Islamic media networks. Among these are middle-class aspirations and interests, which have dominated the public sphere since the liberalization of the Indian economy, including liberalization of broadcasting in 1991 (Fernandes, 2006). Both Zakir Naik's and WIN's television channels cater to such middle-class aspirations, combining them with the quest for a pious transformation of the self.

One of my goals in this article has been to open up the discussion of mediatization of religion to contexts beyond Christianity in the North Atlantic world. But I suggest that Islamic televangelism in India also has other important implications for debates about the mediatization of religion. While highlighting the inseparability of media and religion, the article also demonstrates the need to differentiate between different intersections of media and religion and to pay attention to their interactions. Religious mediation and public religion operate on different levels, and as the relative resilience of established forms of religious mediation especially in the case of WIN has demonstrated, mediainduced changes in one dimension do not necessarily imply changes on the other. Nevertheless, the two dimensions are in fact frequently interconnected, as the influence of media-associated transformations in public religion on the structures of religious mediation has shown in the example of Salafist televangelism. Rethinking mediatization 
along these lines reveals that the impact changes in media practices and mediascapes have on religion may be highly uneven even in the same regional settings and within the same larger religious tradition. Furthermore, while at first sight it appears to be a media makeover of religion, the very phenomenon of Islamic televangelism also demonstrates how actors in religious contexts have domesticated new media practices and media genres in order to strengthen established religious traditions.

\section{Funding}

The author would like to thank Washington University in St. Louis and the Netherlands Organization for Scientific Research (NWO) for supporting the research for this article.

\section{References}

Brosius C (2010) India's Middle Class: New Forms of Urban Leisure, Consumption, and Prosperity. New Delhi, India: Routledge.

Bruce S (1990) Pray TV: Televangelism in America. London; New York: Routledge.

Clark LS (ed.) (2007) Religion, Media, and the Marketplace. New Brunswick, NJ: Rutgers University Press.

Couldry N (2008) Mediatization or mediation? Alternative understandings of the emergent space of digital storytelling. New Media \& Society 10(3): 373-391.

De Vries H (2001) In media res: global religion, public spheres, and the task of contemporary comparative religious studies. In: De Vries H and Weber S (eds) Religion and Media. Stanford, CA: Stanford University Press, pp. 3-42.

Eickelman DF (2005) New media in the Arab Middle East and the emergence of open societies. In: Hefner RW (ed.) Remaking Muslim Politics: Pluralism, Contestation, Democratization. Princeton, NJ: Princeton University Press, pp. 37-59.

Eickelman DF and Anderson J (eds) (1999) New Media in the Muslim World: The Emerging Public Sphere. Bloomington, IN: Indiana University Press.

Eisenlohr P (2009) Technologies of the spirit: devotional Islam, sound reproduction, and the dialectics of mediation and immediacy in Mauritius. Anthropological Theory 9(3): 273-296.

Eisenlohr P (2012) Media and religious diversity. Annual Review of Anthropology 41: 37-55.

Elsayed H (2016) A divine cosmopolitanism? Religion, media and imagination in a socially divided Cairo. Media, Culture \& Society 38(1): 48-63.

Engelke M (2010) Religion and the media turn: a review essay. American Ethnologist 37(2): 371379.

Fernandes L (2006) India's New Middle Class: Democratic Politics in an Era of Economic Reform. Minneapolis, MN: University of Minnesota Press.

Freitag SB (1989) Collective Action and Community: Public Arenas and the Emergence of Communalism in Northern India. Berkeley, CA: University of California Press.

Gräf B and Skovgaard-Petersen J (2009) Global Mufti: The Phenomenon of Yusuf Al Qaradawi. London: Hurst.

Hansen TB (2007) The India that does not shine. ISIM Review 19: 50-51.

Hepp A (2009) Cultures of Mediatization. Cambridge: Polity Press.

Hepp A and Krönert V (2009) Medien-Event-Religion. Die Mediatisierung des Religiösen. Wiesbaden: VS Verlag.

Hirschkind C (2006) The Ethical Soundscape: Cassette Sermons and Islamic Counterpublics. New York: Columbia University Press. 
Hjarvard S (2008) The mediatization of religion: a theory of the media as agents of religious change. Northern Lights 6: 9-26.

Hjarvard S (2016) Mediatization and the changing authority of religion. Media, Culture \& Society 38(1): $8-17$.

Hoover SM (1988) Mass Media Religion: The Social Sources of the Electronic Church. London: Sage.

Juluri V (2003) Becoming a Global Audience: Longing and Belonging in Indian Music Television. New York: Peter Lang.

Khan N (2011) The acoustics of Muslim striving: loudspeaker use in ritual practice in Pakistan. Comparative Studies in Society and History 53(3): 571-594.

Krotz F (2009) Mediatization: a concept with which to grasp media and societal change. In: Lundby K (ed.) Mediatization: Concept, Changes, Consequences. New York: Peter Lang, pp. 21-40.

Larkin B (2008) Ahmed Deedat and the form of Islamic evangelism. Social Text 26(3): 101-122.

Lundby K (2009) Introduction: 'mediatization' as key. In: Lundby K (ed.) Mediatization: Concept, Changes, Consequences. New York: Peter Lang, pp. 1-18.

Lutgendorf P (1995) All in the (Raghu) family: a video epic in cultural context. In: Babb LA and Wadley SS (eds) Media and the Transformation of Religion in South Asia. Philadelphia, PA: University of Pennsylvania Press, pp. 217-253.

Mankekar P (1999) Screening Culture, Viewing Politics: An Ethnography of Television, Womanhood, and Nation in Postcolonial India. Durham, NC: Duke University Press.

Messick B (1993) The Calligraphic State: Textual Domination and History in a Muslim Society. Berkeley, CA: University of California Press.

Metcalf BD (1982) Islamic Revival in British India: Deoband 1860-1900. Princeton, NJ: Princeton University Press.

Meyer B (2004) 'Praise the lord': popular cinema and pentecostalite style in Ghana's new public sphere. American Ethnologist 31(1): 92-110.

Meyer B (2008) Sensational forms: why media, aesthetics, and power matter in the study of contemporary religion. In: De Vries H (ed.) Religion: Beyond a Concept. New York: Fordham University Press, pp. 704-723.

Meyer B (2013) Material mediations and practices of world-making. In: Lundby K (ed.) Religion across Media: From Early Antiquity to Late Modernity. New York: Peter Lang, pp. 1-19.

Meyer B and Moors A (eds) (2006) Religion, Media, and the Public Sphere. Bloomington, IN: Indiana University Press.

Moll Y (2010) Islamic televangelism: religion, media, and visuality in contemporary Egypt. Arab Media \& Society 10: 1-27.

Morgan D (2011) Mediation or mediatisation? The history of media in the study of religion. Culture and Religion 12(2): 137-152.

Pinney C (2002) The Indian work of art in the age of mechanical reproduction: or, what happens when peasants 'get hold' of images. In: Ginsburg FD, Abu-Lughod L and Larkin B (eds) Media Worlds: Anthropology on New Terrain. Berkeley, CA: University of California Press, pp. 355-369.

Rajagopal A (2001) Politics after Television: Hindu Nationalism and the Reshaping of the Public in India. Cambridge: Cambridge University Press.

Rao U (2010) News as Culture: Journalistic Practices and the Remaking of Indian Leadership Traditions. Oxford: Berghahn.

Reetz D (2006) Islam in the Public Sphere: Religious Groups in India 1900-1947. Oxford: Oxford University Press. 
Rock A (2010) Amr Khaled: from Da'wa to political and religious leadership. British Journal of Middle Eastern Studies 37(1): 15-37.

Rudnyckyj D (2010) Spiritual Economies: Islam, Globalization, and the Afterlife of Development. Ithaca, NY: Cornell University Press.

Schulz W (2004) Reconstructing mediatization as an analytical concept. European Journal of Communication 19(1): 87-101.

Silverstone R and Hirsch E (eds) (1992) Consuming Technologies: Media and Information in Domestic Spaces. London: Routledge.

Sreberny-Muhammadi A and Muhammadi A (1994) Small Media, Big Revolution: Communication, Culture, and the Iranian Revolution. Minneapolis, MN: University of Minnesota Press.

Stolow J (2005) Religion and/as media. Theory, Culture \& Society 22(4): 119-145.

Thomas P and Lee P (eds) (2012) Global and Local Televangelism. New York: Palgrave.

Van Der Veer P (2001) Imperial Encounters: Religion and Modernity in India and Britain. Princeton, NJ: Princeton University Press.

Vasudevan R (2011) The Melodramatic Public: Film Form and Spectatorship in Indian Cinema. New York: Palgrave.

Warner M (2002) Publics and counterpublics. Public Culture 14(1): 49-90.

Westerlund D (2003) Ahmed Deedat's theology of religion: apologetics through polemics. Journal of Religion in Africa 33(3): 263-278. 